\title{
Development of Democracy in Multiculturalism through Open Spaces in Indonesia
}

\author{
Dimas Asto Aji An'Amta \\ Sociology and Anthropology Education Department \\ Faculty of Teaching and Education \\ Universitas Lambung Mangkurat \\ Banjarmasin, Indonesia \\ dimas.a@unlam.ac.id
}

\author{
Syahlan Mattiro \\ Sociology and Anthropology Education Department \\ Faculty of Teaching and Education \\ Universitas Lambung Mangkurat \\ Banjarmasin, Indonesia
}

\begin{abstract}
This study discusses how multicultural is wrapped in the dimensions of democracy in Indonesia. The society's understanding of the multicultural and democratic system used by Indonesia is the Indonesian government's task in shaping its citizens to become more mature. Through open space such as film festivals is one way of introducing a multicultural society wrapped with democracy. The research that takes the benchmark of the Cheng-Cheng PO film as the winner of the film festival as its object makes a new step to provide a multicultural understanding to the people. Without tendency to certain parties, the film makes it an effective medium in helping the government to further mature its people in understanding democracy and multiculturalism.
\end{abstract}

Keywords—-multicultural, democracy, public space

\section{INTRODUCTION}

Multiculturalism is a concept which is currently discussed by scholars and academicians. Some people who write the multiculturalism concept are Rawls, Raz, Kymlicka, and Bhikhu Parekh. Every multicultural thinker has his own view of the concept of multiculturalism. Kymlicka calls multiculturalism as something that includes various forms of cultural pluralism and each region has its own challenges [1]. The source of the cultural diversity of a country cannot be separated from the migration done by someone/family/nation in a new area which then they become a minority group in the new place.

Kymlicka uses the concept of multi-nations and polyethnics in the discussion. He seeks to see how minorities in a country gain recognition in autonomy. Autonomy itself is an effort undertaken by society for a better life. This autonomy concept then brought into liberal politics where every nation and ethnic group have the freedom to express their culture, earning the same status as the majority group. The politics of liberal democracy grants the rights of minorities to define national membership by integration into the cultural community and not the descendants.

Plurality in Indonesia seems unchanged, exactly as described by Furnivall fifty years ago. It is the strict sense of medley, for they mix, but do not combine. Each group holds by its own religion, by its own culture, its own ideas, and ways. As individuals, they meet but only in the marketplace in buying and selling. There is a plural society with different sections of the community living side by side but in the same political unit [2]. According to Furnivall, Indonesian society has a variety of cultures in which the differences meet each other in their social interaction.

Every Indonesian citizen has the freedom to access their culture as a form of individual freedom because they have a close bond with their culture. The freedom does not move beyond the language and history that exist in the environment they live in. This freedom remains limited in one's culture and history. It can be seen on how ethnic Chinese lives in Indonesia. Minority groups gain the freedom to express their culture through a range of activities in the social, educational, religious, recreational, and economic spheres that are institutionally embodied in schools, the media, the economy, and others [3]. This is legal as long as the ethnic moves within the majority culture of Indonesia with the embodiment of willingness to use the Indonesia language in daily activities, obey the rules of the country, and others.

However, a minority case, as once reported by Achmad Uzair Fauzan describing the conflict of Parmalim worship building in Medan, Sumatera Utara, unfortunately, happened. This conflict was triggered by a minor view by most of the majority groups in Medan North Sumatra in view of the Parmalim community [4]. This case is evidence that there are still some areas where people have little understanding of the multicultural themselves. However, it is another story whenever a country that has a homogeneous culture will be stable both in the system of government and in social life. When there are certain other groups entering the country, it will create jealousy because majority groups can express their culture, while minorities cannot express their culture and are forced to assimilate into the majority culture. For Kymlicka, culture is a very important thing in the life of society so he rejects the coercion of assimilation in the majority culture. For him, minority groups have a right to their culture.

Indonesia uses a long-standing democratic system. The development of democracy in Indonesia is not a coincidence like goods falling from the sky and it is unfortunate that it is not accompanied by multiculturalism. The view of the meaning of our democracy is practically right to know clearly the essence of democracy as a form of government by the people and for the people. In a very broad sense, democracy is 
not only a political system, but also a social and economic system. Dahl's contribution of thought is useful for defining democracy as a system. Dahl emphasizes the government's responsiveness to the citizen's equal preference politically, as the nature of democracy. Such responsiveness requires citizens who have the opportunity to (1) formulate their preferences, (2) show their preference to other citizens and governments through private and collective action, and (3) give equal weight to their preferences, conducted by citizens [5].

Multiculturalism is the basic capital in creating an ideal democracy. It is due to democracy that must be based on various interests and diversity of backgrounds then made into policies that corresponding to common interests. What would a democracy be if it is without diversity existence? How are the public spaces that try to be made to accommodate the diversity and create a policy deliberation that becomes a representation of all the social aspects that exist?

\section{METHOD}

In this analysis study focusing on Cheng Cheng PO film, the employed method is qualitative research method with its strategy that is discourse analysis. It is matched to the data searched only through dialogue analysis and image frames on Cheng Cheng PO film. This study uses discourse analysis offered by Fairlough. This method was done by connecting text analysis at the micro level with a larger social context, in this case, socio-cultural practice [6]. There are two stages of analysis used namely description and interpretation.

\section{RESULT AND DISCUSSION}

\section{A. Cheng Cheng PO, A Short Film on Multiculturalism Based}

Creating a society that understands and applies the concept of multiculturalism in Indonesia is the main goal for the creation of a harmonious society in running the democratic system. The form of education to multiculturalism to the community can be by making film festival based on multiculturalism. This is as has been done by the nation's children by looking at the problems in Indonesia and trying to come up with the concept of multiculturalism which is then represented through the Cheng short film. It conveys that with the multiculturalism, we can live peacefully in ethnic and religious diversity.

Departing from a film that lifts the concept of multiculturalism in a democratic system having equal rights for every citizen, a film is then produced without any commercial element as its main goal. The idea of a story from a person named Anggi Noen got a positive appreciation especially from the winning of the Short Film Festival Konfiden 2007. The story is very simple as it represents that with the multiculturalism, this nation can live in peace and prosperity. Even though the story is made not from the true story, it is the ideals of the nation's children.

This film is entitled Cheng-Cheng PO, played by fournation boys who still sit in elementary school and come from different religions and tribes. These four elementary school children represent the diversity of Indonesian nation, the descendants of Chinese, Javanese, and Papua. The story begins with a child with a background of ethnic Chinese having problems in paying school fees. If the school fee can not be paid within two weeks, the child of Chinese descent cannot take the final exam of the semester. Then, the three friends who have different background try to help. But their good intentions are still hindered by the final disability and the unwillingness of one parent from the three friends to help. As a result, the three of them try to find a way out by making a lion show.

Barongsai costumes they use are also made from cooperation with the three friends. The materials obtained for the barongsai costumes come from donations of the used goods. Some carry paper, glue paper, color paint, cloth as lion body, and bird cage for lion head. After that, they make the lion show in front of a bakpao stall belonging to the mother of Hans, the son of Thai grace who must pay the school tuition in order to take the final exam of the semester. This performance does not intend to make people around and passer-by pay the show. Instead, they are thinking of how to make Han's mother bakpao cakes are sold. By having this show, there were many people who come watching the lion dance show. These people including the elementary school children watched and bought Han's mother bakpao. The lion dance show earned the income in which at that time enough to cover the payment of Han's school fees to take the exam.

This short film reflects how beautiful the harmony of the diversity that exists in Indonesia if it is implemented together. Even when they want to get the money, it does not mean they picked up from the results of their performances. Instead, it aims to sell Han's mother bakpao. This means that the film reflects without having to beg for the results of their performances even though they actually have the right to collect from the performance of the lion dance. The purpose of this film is to expect that multicultural can be widely accepted in the community. Because with this diversity is making Indonesia's wealth so great. With multiculturalism, it is expected to preserve the culture in each region and the formation of solidarity as a strong Indonesian citizen intact.

This short film festival program may also be able to make new media in giving an understanding of Indonesian citizen in socializing multicultural concept, with fun media and full of creativity. Because we know that people who have different cultural backgrounds, of course, have a different perspective in looking at the concept of multicultural in Indonesia. The societal pathology that circulates so far in seeing the differences makes a clear affirmation that society is still in the learning process. It is either sensitivity to a particular culture or sensitivity to a particular religion.

\section{B. Community Pathology in Cultural Diversity and Theology}

People who have various heterogeneous backgrounds create perceptions in a discourse on their respective variants. People who have low education whether they are primary school or who are not in school automatically have differences in response to a circulating discourse. Similarly, people have diversity in religious differences in understanding when undergoing faith belief. In any culture people have 
differences. Both in terms of tradition inherent downhill from their ancestors or ancestors as well as traditions began to experience assimilation with neighboring cultures. This difference can also make the difference between the perception of discourse circulating in the community.

The diversity that occurs in society is basically a common thing in social life. The diversity that exists can sometimes make people have more knowledge about their own concept with the concept outside of itself based on their glasses or sometimes can become a polemic from the emergence of the seeds of the conflict in the future. The emergence of conflicting cause can be based on several angles, first of all, the idea of their culture or their own true religion and regard culture or religion outside of them. Secondly, the unwillingness of the community to study or understand why and how differences in culture and religion in society itself exist.

The strong doctrinal influences of their respective cultures and religions also make it difficult for the concept of pluralism which the government seeks to implement in such heterogeneous societies. It is coupled with the presence of movements that further highlight one of the peculiarities of their religion, such as militant movement of Islamic fundamental. This movement put more into a corner any teaching outside of their teachings, which then create the occurrence of friction-friction in the social order in society. Obviously, in the movement, they show for the existence of the Islamic religion in opening up is very far away.

The polemic happened not only from movements like fundamentalists. Unfortunately, it also happens in a large institution in Indonesia that is from Majelis Ulama Indonesia (MUI). On July 28, 2005, the MUI issued a fatwa prohibiting pluralism. In the fatwa, religious pluralism, as the object of the question, is defined as "a notion that teaches that all religions are the same, and; therefore, the truth of every religion is relative. Therefore, every religious believer should not claim that only his religion is true while other religions are wrong Pluralism also teaches that all followers of religion will enter and live and coexist in heaven ". Thus, the MUI declares that Pluralism in its contexts is contrary to the teachings of Islam [7].

The lack of clarification of the definition of multiculturalism and pluralism has made polemics in some areas as well as the like of MUI in view of diversity. The terms used in pluralism still seem diverse as well in putting the use of the word multiculturalism. In a large dictionary of Indonesian pluralism is a plural society (related to the social system and its political). Meanwhile, the word multicultural dictionary in the Indonesian language more directed to the symptoms in a person or a society that is characterized by the habit of using more than one culture. From this sense, it can be said there is still siltation in defining or in the use of the word.

According to the origin, he said pluralism comes from the English word. When referring from the English Wikipedia, the definition of [eng] pluralism is: "In the social sciences, pluralism is a framework of interaction in which groups show sufficient respect and tolerance of each other, that they fruitfully coexist and interact without conflict or assimilation". Or in the Indonesia language: "An interaction framework in which each group displays respect and tolerance to one another, interact without conflict or assimilation." Understanding pluralism taken from the English language is sometimes still a polemic in Indonesia for some circles. Because there is a fundamental difference between "pluralism" and its initial sense of pluralism that means: a) pluralism overwhelmed by religious spirit, not just sociocultural, b) pluralism is used as a reason for mixing between religious teachings, and c) pluralism is used as a reason for changing doctrine a religion to conform to other religious teachings [8].

The word "pluralism" itself in its non-theological discourse also has some insight. Some use it fairly neutrally (e.g. John Bowen when referring to "normative pluralism"); there are those who refer to it as a distinctive response that is not necessarily related to religion (e.g. the use of the term "gender pluralism", to refer to the view that recognizes the existence of gender diversity) [9]. Then, like the anthropologist Heddy Shri Ahimsa-Putra, using pluralism's understanding as a fact of cultural plurality, though he also sees that the existence of "ism". It makes a problematic thing if the term is descriptively intended. Pluralism in its view creates a mosaic that still contains cultural segregation. Pluralism is more passive, while multiculturalism is more active, in the sense of not only accepting plurality but also encouraging mutual recognition and respect [9].

Meanwhile, the anthropologist Parsudi Suparlan has his view of the semantics between pluralism and multiculturalism. He contrasted the "multicultural society of Indonesia" that was to be built as a result of reforms with a "plural society" order of life. The term "plural society" does have a long history, used by the Furnival to describe a pluralistic and segregated colonial society [9]. The overlapping of pluralism and multiculturalism does not make the development of democracy in Indonesia hampered. However, these developments need to be developed further to achieve an ideal democracy with the spirit of multiculturalism.

However, if you look with the eyes of democracy, the existence of multiculturalism is the most important thing in building a democratic country. Multiculturalism is expected to appear a representation of each religion and culture and then discussed in a container. In the discussion with representation from various circles, it produces a policy that can be approved and beneficial for one another with other circles. Although we know how well a policy derived from the discussion, still there is a side that is not profitable from certain circles. However, with the policy of the result of representative democracy at least minimize the occurrence of conflicts that can harm many parties. Therefore, a State which has heterogeneity in culture and religion is expected for the availability of public spaces in democracy.

\section{Open Space for Multicultural Representation on Democracy Development In Indonesia}

Public spheres are commonly known as open spaces. In Habermas's theory which discusses the open spaces states that the public sphere is the space (actual and abstract) for 
communicating and opinion formation. This public space is the first place for all communication, and then potentially to the formation of opinion [10]. In the societies with heterogeneity living in a democratic country like Indonesia, people are trying to incorporate all the resulting policies capable of representing all its aspects. With the existence of open space, it is intended to create a space of discussion of the diversity that exists in the community. Open spaces can be a gathering place for various cultures, religions, and other communities to discuss something and make it an opinion.

Democracy will be complete if the diversity that exists in society can be fully represented. Public space is one of the suitable containers to bridge the existing diversity. Problems arise when media intervention makes the existing public sphere blurred. The discourse in the opinion of multiculturalism may become indeterminate, both of which support the existence of multiculturalism to the rejection of multiculturalism. According to Habermas, "as long as it is in the public sphere, the media tend to prefer to contradict their normative self-understanding, drawing news material from powerful and well-organized information producers. As long as they prefer more degrading media strategies rather than increasing the discursive level of public communication, the issues tend to start in and are managed from the center rather than following the spontaneous stream from the periphery [10].

The discourse on multiculturalism also exists when the intervention of the media makes it can appear suddenly and can also disappear without knowing where it went. Whatever is done by the media seems to be true when the media review continuously from various aspects by seeking justification that seems to be true. It is directed to the media, more directed to profit-oriented, without any more idealism attached to the media. Then, what about the public space for multiculturalism in its representation on the participation of democracy today?

The representation of multiculturalism in a democracy must conform to the concept of pluralism itself. According to Thomas Hobbes, representing the words and actions of others must be done by contract. The contract that governs the representative as an actor must be with the authority of the electorate as the author of the story. However, given the authority on the representative to act on his behalf, the author of the story also agrees to accept any action taken on his behalf. Thus, the voter as the author of the story must be responsible for all actions taken by the representatives as if he were to take the action himself [11].

Further, with the representation of each religion and culture, it makes pluralism that has been thrown into society with a definition that has not been very clear can be realized in this nation's democratic system. By not bending or misusing the existing of open spaces and throwing away will set up the profit oriented. Thus, the participation of citizens in a democracy can be run in accordance with the mandate of the constitution prevailing in Indonesia by optimizing the function of representation itself. Multiculturalism that has been debated is no longer just a discourse without anti-climax but goes according to the direction that will be directed from the existing concept. Then, it develops without just rhetoric, but becomes a reality that goes according to society.

\section{CONCLUSION}

The Cheng-Cheng PO fiction film based on multiculturalism affirms that coexistence in different religions and cultures turns out to have its own color. Compared to a homogeneous society with the same understanding and tradition, it does not make us mature faster about a difference. This is due to the difference we can better understand that there are communities and other communities outside us. Even though, broadly it is still overlapping the clear definition of pluralism and multiculturalism in the community. Apart from that, the community should keep each other without overly questioning the diversity that exists in the community as a problem.

The government's program of understanding multiculturalism and democracy is not enough to include in the education curriculum in Indonesia. Rather through other media such as giving space to the public in expressing the diversity is more creative and wrapped with the concept of multicultural itself. How to express the creativity of the citizens by holding a short film festival based on the spirit of democracy and multiculturalism in Indonesia. Besides, it also provides an open discussion space to the general public without any intervention of the parties who take advantage of the discussion space. Therefore, the spirit of democratic development must coincide with the spirit of multiculturalism in order to obtain a form of democracy near the ideal.

Meanwhile, the phenomenon like the fundamentalists of Islam is also a Parmalim community in North Sumatra summarized as a new color that does not need to annoy its existence. Full attention should be given is the red line about providing an understanding of what it is multiculturalism in the development of democracy and how to preserve it in Indonesian society that has not so deep understanding of multiculturalism. Existing public spaces, whether it is used optimally as a forum of various opinions from the gathering of various backgrounds of each individual. With that, the argument in circulation makes society more mature to see multiculturalism as an ideal concept in the development of a democratic system in Indonesia.

\section{REFERENCES}

[1] Kymlicka, Kewargaan Multikultural, Jakarta: LP3ES, 2002

[2] M. Nurkhoiron, (ed), Hak minoritas; multikulturalisme dan dilemma Negara Bangsa, JAKARTA: yayasan TIFA, 2007

[3] B. Parekh, Rethinking Multiculturalism, Keberagaman Budaya dan Teori Politik, Yogyakarta: Impulse dan Kanisius, 2008

[4] M. Nurkhoiron, (ed). Op. Cit

[5] G. Sorensen, Demokrasi Dan Demokratisasi: proses dan prospek dalam sebuah dunia yang sedang berubah, Yogyakarta: Pustaka Pelajar, 2003

[6] Eriyanto, Analisis Wacana Pengantar analisis teks media, Yogyakarta, PT LKIS Cemerlang, 2012

[7] Decision Fatwa Majelis Ulama Indonesia Nomor: 7/Munas VII/MUI/11/2005 about Pluralism, Liberalism, and Secularism Religion. Ditetapkan di : Jakarta pada tanggal: 21 Jumadil Akhir 1426 H/28 Juli 
2005 M. Musyawarah Nasional VIIMajelis Ulama Indonesia, Pimpinan Sidang Komisi C Bidang Fatwa

[8] http://id.wikipedia.org/wiki/Polemik_pluralisme_di_Indonesia di unduh tanggal 7/7/2014 14.37 wib

[9] Z.A. Bagir, dkk, Pluralisme Kewargaan: arah baru politik keragaman Indonesia, Bandung : Mizan Media Utama, 2011
[10] J. Edkins and N. Vaughan-Williams, Teori-teori Kritis Menentang Pandangan Utama Studi Politik Internasional, Yogyakarta: Pustaka Pelajar, 2013

[11] N. Soeseno, Representasi Politik, Perkembangan Dari Ajektiva ke teori, Pusat Kajian Politik Departemen Ilmu Politik FISIP UI, 2013 